\title{
English and Scottish Exiles in Northwest Germany \\ c. 1683-1709
}

Les exilés anglais et écossais dans le nord-ouest de l'Allemagne c. 1683-1709

\section{Kathrin Zickermann}

\section{(2) OpenEdition \\ 1 Journals}

\section{Electronic version}

URL: https://journals.openedition.org/etudesecossaises/217

DOI: 10.4000 /etudesecossaises. 217

ISSN: 1969-6337

\section{Publisher}

UGA Éditions/Université Grenoble Alpes

\section{Printed version}

Date of publication: 30 September 2010

Number of pages: 41-58

ISBN: 978-2-84310-173-1

ISSN: 1240-1439

\section{Electronic reference}

Kathrin Zickermann, "English and Scottish Exiles in Northwest Germany c. 1683-1709", Études écossaises [Online], 13 | 2010, Online since 30 September 2011, connection on 11 April 2023. URL: http://journals.openedition.org/etudesecossaises/217 ; DOl: https://doi.org/10.4000/ etudesecossaises. 217 


\section{English and Scottish Exiles in Northwest Germany c. 1683-1709}

Research conducted by historians such as Ginny Gardner and Douglas Catterall has shown that the United Provinces became a safe haven for the Scottish Calvinist exiles who left the British Isles in the wake of the restoration of the Stuart monarchy in $1660 .{ }^{1}$ The Scottish exile community which established itself in the Dutch towns centred around Scottish and "English" churches which provided aid for fellow countrymen not least through poor relief. ${ }^{2}$ The core group of the exiles consisted of a group of ministers who in some cases became incumbents of these Scottish churches. They were joined by a group of approximately 170 laymen as well as by a number of expatriates associated and sympathising with them. ${ }^{3}$ Although the group of lay exiles was attached to the Presbyterian faith their motivation to leave the British Isles was not always rooted in their religion but sometimes in political intrigue - albeit the two can be hard to separate. Some men were suspected of being involved in the Bothwell Bridge Rising (1679) or in the alleged Rye House Plot conspiracy to kill Charles II and his brother in $1683{ }^{4}$

What remains hitherto unknown is that from 1683 some North West German territories and cities received intensive attention from English and Scottish religious and political exiles who had left or were in the process of leaving the British Isles to take refuge on the continent. Under the leadership of the Englishman William Waller a group of exiles took up negotiations first with the Imperial city of Bremen and then with duke

1. Douglas Catterall, Community Without Borders: Scots Migrants and the Changing Face of Power in the Dutch Republic, c. 1600-1700 (Leiden/Boston/Cologne, 2002); Ginny Gardner, The Scottish Exile Community in the Netherlands 1660-1690 (East Linton, 2004).

2. Ginny Gardner, The Scottish Exile Community, pp. 1-2, 29-30. Although being called "English" the congregations of these churches were often predominantly Scottish. A publication on English exiles in the United Provinces which could mirror Catterall's or Gardner's analysis of the Scots is so far missing.

3. Ibid., pp. 9-24.

4. Ibid., pp. 17-8. 
Georg Wilhelm of Braunschweig-Lüneburg who granted extensive privileges to individuals and families of the "reformed faith" regardless of their nationalities. These freedoms led not only to English and Scottish but also to French and Dutch migration of religious and political exiles as well as economic opportunists. This essay analyses the aims of the English and Scottish exiles, their negotiations with the local authorities in North West Germany as well as the success and failure of the set up of the communities in Bremen and Lüneburg and their lasting impact on individual exiles. It also examines whether the diverse migration of individuals of several nationalities resulted in the formation of a single British or multi-ethnic religious community or whether the migrants organised themselves in several groups, divided by nationality or other criteria. ${ }^{5}$

Since the Restoration of 1660 the United Provinces provided a relatively safe environment for religious exiles. However, the Treaty of Breda (1667) between Charles II and the Dutch government stated that those Britons accused of regicide could be extradited without formal demand from London and that political exiles were to be banished on the request of the Stuart Court. ${ }^{6}$ Although the Dutch authorities tended to be slow to comply with demands, the climate in the United Provinces became more insecure in the aftermath of the Rye House Plot, as the capture and subsequent execution of the suspect Sir Thomas Armstrong in 1684 demonstrated. ${ }^{7}$ From November 1683 the Englishman and Calvinist William Waller negotiated with the senate of the Imperial city of Bremen for the settlement of English and Scottish exiles. ${ }^{8}$ The latter had been a London JP (1678-1681) and Westminster MP (1679-1681) during which time he had been demonstrably anti-Catholic in behaviour. Waller was temporarily arrested for debts in 1681 and left the British Isles shortly after his release in the increasingly hostile climate of Stuart Britain. ${ }^{9} \mathrm{He}$ was accompanied to Bremen by the Scot George Melville (the future 1st Earl of Melville) and the latter's Scottish servant Adam Freer. As a suspect of the Rye House Plot George Melville had been forced to leave

5. This article will thus complement existing studies on Scottish migration and community building during the early modern period. An overview over these is given in Christopher Smout's foreword in Alexia Grosjean and Steve Murdoch (eds), Scottish Communities Abroad in the Early Modern Period (Leiden/Boston, 2005). Significant works which have been published since include Steve Murdoch, Network North: Scottish Kin, Commercial and Covert Associations in Northern Europe 1603-1746 (Leiden/Boston, 2006) and David Worthington (ed.), British and Irish Emigrants and Exiles in Europe, 1603-1688 (Leiden/Boston, 2010).

6. Ginny Gardner, The Scottish Exile Community, pp. 104-6.

7. Richard L. Greaves, "Sir Thomas Armstrong", $D N B$ (online publication).

8. His presence is briefly noted in Steve Murdoch, Network North: Scottish Kin, Commercial and Covert Associations in Northern Europe 1603-1746 (Leiden/Boston, 2006), pp. 111-2.

9. Alan Marshall, "Sir William Waller (c. 1639-1699)", DNB (online publication). 
the British Isles for the United Provinces, where he was joined by his son David Melville, the Earl of Leven. ${ }^{10}$ The Melvilles certainly met with other exiles in the Netherlands - including William Waller-and attached themselves to the court of the Prince of Orange. ${ }^{11}$

On 14 December 1683 Freer informed Andrew Russell, the Scottish factor at Rotterdam and sympathiser with the Scottish exile community, of the proceedings in Bremen. He stated that William Waller had informed him that "any person, that thinks themselves not secure enough in Holland may come here to Bremen, where they will be assured of all the protection which this state is capable to give" 12 revealing that it was indeed safety issues which motivated the exiles to turn to North West Germany for sanctuary. Although it did not feature any pre-existing Scottish or English expatriate communities, Waller's choice of the city of Bremen for his project rather than another location is not too surprising. The local authorities had for many years previously been open to receiving individuals of the reformed faith coming in the Calvinist city. ${ }^{13}$ For example, in 1620 they had seriously considered the application of a group of Presbyterian English merchants who had previously settled in Hamburg. ${ }^{14}$ Moreover, Bremen's confession had attracted some Scottish ministers and students who may or may not have been religious exiles themselves as evidenced, in August 1668, by a Scot called John Ruthven who sat his divinity exam in the city. ${ }^{15}$ Also, a D. Niclas Rolandus, who was styled Scoto-Britannus, conducted a service on behalf of a local minister on 29 September $1682 .{ }^{16}$ It may have been him who liased with Robert Hamilton, the Scottish agent of the United Societies, a union of various radical Cameronian groups with bases in Leuwaarden and Groningen, who received a sum of eighty "ducatoons" from Bremen's ministry. ${ }^{17}$ Although no evidence has yet come to light it is inconceivable that Rolandus did not help with Waller's negotiations in 1683.

10. Margaret D. Sankey, "David Melville, Third Earl of Leven and Second Earl of Melville (1660-1728)", DNB (online publication); John R. Young, "George Melville, Fourth Lord Melville and First Earl of Melville (1636-1707)", DNB (online publication).

11. Ibid.

12. NAS, Russell Papers, RH15/106/494, Adam Freer to Andrew Russell, Bremen, 14 December 1683.

13. Anne E. Dünzelmann, Vom Gaste, den Foden und den Fremden: Zur Ethnographie von Immigration, Rezeption und Exkludierung Fremder am Beispiel der Stadt Bremen vom Mittelalter bis 1848 (Berlin/Hamburg/Münster, 2001), pp. 132-3.

14. Ibid., p. 134. The settlement of these Englishmen failed for reasons which are hitherto unknown.

15. Staatsarchiv Bremen, Acta Venerandi Ministerii 1667-1707, 2-T.2.b.4.c., p. 6, 2 August 1668.

16. Ibid., p. 86, 14 and 29 September 1682.

17. I would like to thank Mark Jardine for providing this information. Michael Shields, Faithful Contendings Displayed (Glasgow, 1780), pp. 207-8. The donation of this sum is not listed in the records of the ministry in Bremen. Staatsarchiv Bremen, Acta Venerandi Ministerii 1667-1707, 2-T.2.b.4.c. 
The latter made extensive requests to the senate, including the foundation of a church with two ministers to be paid by the city as well as the permission for the congregation to have its "own discipline" in church matters. In addition, he requested citizen rights and privileges for the migrants as well as admission to the guilds at only half the usual payment. Furthermore, Waller planned to encourage the opening of a wool factory, requesting the right to employ poor children for seven years of their lives and demanding an exemption from excise and consumption taxes for a duration of thirty years. Also, Waller asked for the granting of building sites for houses which the incomers were to keep tax free for forty years. ${ }^{18}$ Thus Waller attempted to create a community big enough to justify and sustain its own congregation and elders, probably based on the model of the Scots and English churches in the United Provinces. In terms of economic and political advantages, however, he aspired to an integration of the incomers with the indigenous population through the acquisition of citizen rights with long-term economic privileges. For his own benefit and to secure a livelihood Waller asked to be made commandant, and the community would certainly have benefited from Waller's employment in this capacity which would have placed one of their own in a powerful position within the city. ${ }^{19}$ Waller's demands reveal that economic opportunities were crucial to him and that he intended to attract a large group of exiles and expatriates to Bremen. This group which would be commercially beneficial to the city was without doubt intended to shelter a smaller group of political exiles such as George Melville whose presence alone would presumably not have been acceptable to the authorities.

Waller's requests were met more than half way by the local authorities, demonstrating their willingness to receive the foreigners in their midst. On 1 December 1683 Waller was employed by the city at a salary of 1,000 Imperial dollars by a contract which made him commanderin-chief of the local militia. ${ }^{20}$ In addition, Bremen's officials approved the use of a local church (Klosterkirche) at certain times by the immigrants as well as the employment of two ministers who were to be paid by the congregation. ${ }^{21}$ Furthermore, they granted free citizen rights to those arriving within the following three years as well as the exemption from

18. Staatsarchiv Bremen, Wittheitsprotokolle 1683-1684, 2-P.6.a.9.c.3.b.14, pp. 473-4, 23 November 1683 .

19. Ibid., p. 481, 30 November 1683.

20. Staatsarchiv Bremen, Offiziere des Stadtmilitärs, 2-R.5.d.13.a.19, Appointment, William Waller, 1 December 1683; See also Steve Murdoch, Network North, pp. 111-2.

21. Stadtarchiv Lüneburg, Gewerbesachen, G3e No. 2, Privileges granted to the English Manufacturers by the City of Bremen (copy), Bremen, 1 December 1683. 
direct taxes for twenty years. Moreover, the incomers were offered building sites for houses and were said to be allowed to keep their houses tax free for a period of ten years. However, they were expected to pay consumption taxes. In order to facilitate the establishment of factories, the privileges stated further that both male and female children in the poor houses would be urged to work in the factories for seven years in return for board and lodgings. In addition, the admission of craftsmen was permitted in principle (and for a fee) but only if it did not violate the rights of the local guilds. ${ }^{22}$

Notably, these privileges were given to "families of true reformed religion" thus subsuming not only Scots and Englishmen but also other nationals. In his letter to Andrew Russell, Freer stated that Waller had promised to send for a minister for "any Scots or English" who would settle in Bremen revealing that the community was envisaged as "British" from the outset. ${ }^{23}$ Without doubt Waller had either initiated or was at least content with the permission for all nationals to profit from the new rights as this would enhance the chances of inviting a profitable community to Bremen. In fact, it was probably Waller himself who tried to attract a particular French entrepreneur. The latter (who has not yet been identified) had arrived in Amsterdam from France and aimed to open a wool and silk factory in Bremen, to which end he was accompanied by twenty skilled employees. ${ }^{24}$ His request was entered into the council's minute book under the headline "English families" revealing Waller's involvement and his endeavour to establish a multi-ethnic community. Freer approved of the favourable conditions offered by the city of Bremen and informed Russell of the possibility of acquiring citizen rights as well as the cheap prices for food and houses. ${ }^{25}$ In addition, he stated that the place would be attractive to students as it featured a college with thirteen to fourteen professors. ${ }^{26}$

Despite the positive outcome of Waller's negotiations the reformed community in Bremen never materialised due to external pressure on the local authorities. The English resident at Hamburg, Sir Bevil Skelton, informed Charles II and other Stuart diplomats about the developments.

22. Ibid. Anne E. Dünzelmann has transcribed (another version of) this document and mentions Waller's negotiations. However, she fails to identify him or to contextualise his discussions with the senate. Dünzelmann, Vom Gaste, pp. 135-6.

23. NAS, Russell Papers, RH15/106/494, Adam Freer to Andrew Russell, Bremen, 14 December 1684.

24. Staatsarchiv Bremen, Wittheitsprotokolle 1683-1684, 2-P.6.a.9.c.3.b.14, p. 501, 25 January 1684 .

25. NAS, Russell Papers, RH15/106/494, Adam Freer to Andrew Russell, Bremen, 14 December 1684.

26. Ibid. 
Sir Richard Bukstrode passed on the following information from Skelton to Lord Preston:

Sir William Waller plays the devill at Bremen, which is like to be the nest of all those persons accused of the last conspiracy, that my Lord Mevin (Melville) and many more of that stamp, are there, as also Armstrong ${ }^{27}$ and Ferguson $^{28}$, and that they expect the Duke of Monmouth there very speedily; they speak most scandalously of the King and Duke and style Waller a second Cromwell. ${ }^{29}$

It was also probably Skelton who advised Charles II in March 1684 that Waller was "drawing to him all the disaffected persons he can under pretence of setting up a woollen manufacture" trying to ship whole families from Yarmouth to Bremen - an action which was to be hindered at all costs. ${ }^{30}$ This direct linking of groups of Scottish and English exiles and the attempts to take still more Englishmen directly out of England again confirms the pan-British nature of the Bremen exiles and their projected community. On the receipt of communication from Charles II the senate of Bremen decommissioned William Waller in order not to jeopardise trade relations with the British Isles. ${ }^{31}$

The city's magistrates were eager to declare that only three Englishmen had arrived after December 1683, of whom two had married in the city and one had died, indicating that no large group of dissenting individuals had been welcomed there. ${ }^{32}$ However, Skelton's accusations of Waller attracting suspected conspirators to Bremen were not unfounded. We know that George Melville and Adam Freer were present in the city along with Melville's son David, the Earl of Leven. Leven was certainly in Bremen in January 1684, from where he communicated with

27. Sir Thomas Armstrong was a suspect of the Rye House Plot and — as previously stated — was captured executed in 1684. See Greaves, "Sir Thomas Armstrong", DNB (online publication).

28. Robert Ferguson, son of William Ferguson of Badifurrow in Aberdeenshire, moved to London in the 1650s where he became active in Whig politics by the late 1670s. After becoming a suspect he fled to the continent, initially to Amsterdam. He was one of Monmouth's main advisors and took part in the invasion. Thereafter he managed to escape once again to the continent. Melinda Zook, "Robert Ferguson (d. 1714)", DNB (online publication).

29. HMC, Seventh Report (London, 1879), p. 386, Richard Bulstrode to Lord Preston, Brussels, 13 March 1684.

30. CSPD, 1684, p. 327, Secretary Jenkins to the Earl of Yarmouth, Whitehall, 15 March 1684.

31. Staatsarchiv Bremen, Wittheitsprotokolle 1683-1684, 2-P.6.a.9.c.3.b.14, pp. 543-4, 2 and 7 May 1684; Offiziere des Stadtmilitärs, 2-R.5.d.13.a.19, Charles II to Bremen Senate, Windsor, 7 April 1684; Offiziere des Stadtmilitärs, 2-R.5.d.13.a.19, Release of William Waller, 2 May 1684; Offiziere des Stadtmilitärs, 2-R.5.d.13.a.19, Bremen Senate to Charles II, Bremen, 2 May 1684.

32. Staatsarchiv Bremen, Offiziere des Stadtmilitärs, 2-R.5.d.13.a.19, Bremen Senate to Charles II, Bremen, 18 January 1684. 
Russell under the pseudonym David Barclay. ${ }^{33}$ Furthermore, the Scot Major George Low, who was later to support the cause of the Duke of Orange, resided in the city until his death in 1699 and commanded the local infantry there, thus working closely with Waller as commandant. ${ }^{34}$ He certainly accommodated the dissident Adam Freer in his house and it is likely that George Melville and his son also found shelter there. The latter was certainly in communication with Low in 1689 and it is probable that both men had either established contact in Bremen or before their stay there. ${ }^{35}$ Furthermore, George Melville was financially supported by a "friend" whom he expected to arrive in Holland soon in order to receive repayment for what he had spent on Melville. It is likely that this acquaintance was the Scottish merchant Gilbert Spence who resided in Bremen from the early 1670s. His contact with Freer can be proven as he sent his regards to Andrew Russell in one of his letters. The merchant's contacts with and occasional business trips to the Netherlands make this connection all the more likely particularly given the known link with the Bremen exiles. ${ }^{36}$ That we cannot identify Spence for sure is not surprising given that he would have wanted any assistance to the exiles be kept a secret due to his strong business links with the British Isles. If Spence was the benefactor, he was only one of several sources of income for Melville. Russell himself took care of some of Melville's business transactions which also involved the second Scottish agent in Rotterdam, James Gordon and after his death in early 1684, the latter's son. ${ }^{37}$ Also, a Mr Dick frequently appears in Freer's and Leven's correspondence as being present in Bremen but it is highly likely that this name was used as a false identity for George Melville himself. ${ }^{38}$ There is no further proof that Melville's fellow conspirators Thomas Armstrong and Robert Ferguson or indeed the Duke of Monmouth moved to Bremen during the months

33. NAS, Russell Papers, RH15/16/532/9, David Baclay alias Leven to Andrew Russell, Bremen, 26 January 1684; For more information on Leven see Margaret D. Sankey, "David Melville, Third Earl of Leven and Second Earl of Melville (1660-1728)", DNB (online publication).

34. Staatsarchiv Bremen, Offiziere des Stadtmilitärs, 2-R.5.d.13.a.19, Petition, Ilsa Sprado to Bremen Senate, Bremen, without date. Ilsa Sprado petitioned the Bremen senate to continue payment of her late husband's salary for another two or three months to cover his funeral costs. Low had died in April 1699.

35. NAS, Russell Papers, RH15/106/689, George Low to Andrew Russell, Bremen, 3 August 1689.

36. Steve Murdoch, Network North, p. 152.

37. NAS, Russell Papers, RH15/106/532/8, Adam Freer to Andrew Russell, Bremen, 11/21 January 1684; Gardner, The Scottish Exile Community, p. 77.

38. NAS, Russell Papers, RH15/106/532/8, Adam Freer to Andrew Russell, Bremen, 11/21 January 1684. This is further confirmed by a letter from George Low who asked Russell in May 1685 about Mr Dick's well-being. As George Melville was likely to be in the Netherlands at this point it is probable that the name was continuously used as his pseudonym. NAS, Russell Papers, RH15/106/576/10, George Low to Andrew Russell, Bremen, 13 May 1685. 
before Waller's eviction although Skelton seems emphatic they were there. In any case the presence of Waller and the Scottish exiles proves that a small but significant Anglo-Scottish network operated in the city and maintained important links to sympathisers in the United Provinces.

After Waller's dismissal the city of Bremen was no longer the hub of the exile community in North West Germany despite Low's and Spence's continued presence there. Instead the exiles' interest shifted to another territory whose ruler had previously proven himself to be sympathetic to Calvinist exiles. This was the Welfenian duchy of Braunschweig-Lüneburg under Georg Wilhelm, who governed from his residency in Celle. The Lutheran duke had taken the Huguenot Eléonore Desmier d'Olbreuse as his wife. Her influence and favour drew a number of her fellow-believers to Georg Wilhelm's court, where they were allowed to hold reformed services in her private rooms in the castle. ${ }^{39}$ At the same time a number of Huguenot officers found employment in Georg Wilhelm's army, whose military strength was dependent on the intake of foreigners. ${ }^{40}$ Among his military leadership was also the Scot and Major-General Andrew Melville who acquired an influential position at the court in Celle and within the French reformed community. ${ }^{41}$ Andrew Melville was a kinsman of George Melville, whose acquaintance he had perhaps made as early as 1651 when he received help from a relative of that name in London as a refugee after the battle of Worcester. ${ }^{42}$ Furthermore, Andrew Melville was in contact with George Melville's son, the Earl of Leven, who assisted him in acquiring a Scottish birth brief in 1683. ${ }^{43}$ These connections linked Andrew Melville to William Waller and it is more than likely that it was the Major-General who initiated - or at least assisted in - talks between the Englishman and duke Georg Wilhelm.

The latter granted a privilege on 9 August 1684 to foreign families and individuals of reformed faith who were willing to settle in the Lutheran town of Lüneburg ${ }^{44}$ regardless of their nationality. By so doing he hoped

39. Andreas Flick, “,Der Celler Hof ist ganz verfranzt": Hugenotten und französische Katholiken am Hof und beim Militär Herzog Georg Wilhelms von Braunschweig-Lüneburg", Hugenotten, vol. 72, no. 3, 2008, pp. 102-6.

40. Ibid.

41. Ibid., p. 95. A visible sign of Melville's standing is provided by the seating order of the first official French reformed church in Celle in 1700 which reserved the first bench left of the chancel to "the old General-Major von Melville" and his family.

42. Torrick Ameer-Ali (ed.), Memoirs of Sir Andrew Melville (London, 1918), p. 135; Steve Murdoch, Network North, p. 25.

43. RPCS, Third Series, 1683-1684, pp. 114-5, Supplication, Sir Andrew Melville, without date/ place.

44. Lüneburg lay within the duchy of Braunschweig-Lüneburg at the river Ilmenau, a side arm of the river Elbe. 
to populate his territory and to enhance his economy. ${ }^{45}$ In this edict the duke gave extensive rights to the foreigners in religious, economic and political terms. He permitted both public and private reformed worship, promising the establishment of a church in the event that the reformed community was to increase in size. The migrants were to be allowed to propose two ministers whose salaries were to be paid by the duke for the first two years and, additionally, a reformed school was to be established. The incomers were to receive citizen rights free of charge under the condition that they swore the usual oath of citizenship, after which they would be allowed to trade, to open factories or to work as craftsmen without any hindrance from the local guilds. Additionally, if the foreigners so wished they were to be received into the guilds for a small fee. Moreover, the new entrepreneurs were to be assisted in the establishment of factory houses. They were also allowed to employ children for the duration of seven years in return for the provision of cloth and victuals or other conditions which the entrepreneurs were to negotiate with the children's relatives. In order to promote the sales of products from the factories their goods were to be given preference within the duchy, especially at court and in supplying the militia. Furthermore, the foreigners were exempted from tolls on imported and exported goods transported by land or water to or from Lüneburg (with the exception of the Elbe tolls at Hitzacker and Schnackenburg) as well as from consumption taxes for the following twenty years. However, they were to pay excise as well as some other minor local taxes. As a further incentive, the foreigners were exempted from quarters and other citizen duties as well as from direct taxes for twenty years. Nevertheless, in order to avoid complaints from the local citizens they were to pay a voluntary contribution in relation to their standing and income. ${ }^{46}$

The timing and the content of this edict leave no doubt that it was initiated by William Waller who had not given up on his aim of establishing a multi-ethnic reformed community in North West Germany. Indeed Waller himself was put in charge of the settlement of foreigners at the Lutheran town of Lüneburg in 1684, where he acquired the position of governor with an annual salary of 1,500 Imperial dollars. ${ }^{47}$ This offer

45. Various copies of this document exist, including a French translation. The privilege has been printed in several secondary studies, for example in Thomas Klinebiel, Die Hugenotten in den welfischen Landen. Eine Privilegiensammlung (Bad Karlshafen, 1994), pp. 47-52. An original copy can be found in Stadtarchiv Lüneburg, Gewerbesachen G3e No. 2, Privileges issued by Georg Wilhelm, Celle, 9 August 1684.

46. Ibid.

47. Stadtarchiv Lüneburg, Gewerbesachen, G3e No. 2, Appointment, William Waller, Celle, 30 July 1684; Wilhelm Reinecke, Geschichte der Stadt Lüneburg, vol. 2 (Lüneburg, 1933), p. 35. 
was conditional and only made on the provision that Waller was successful in attracting profitable migrants to the duchy. ${ }^{48}$

Interestingly, the privileges issued by Georg Wilhelm have hitherto been misunderstood by historians such as Andreas Flick, Walter Mogk, Hartwig Notbohm or Arnulf Siebeneicker. They assumed that Georg Wilhelm aimed to establish a Huguenot colony in Lüneburg and that the freedoms granted on 9 August 1684 must thus be seen as privileges primarily or exclusively granted to French reformed exiles (Hugenottenprivileg). ${ }^{49}$ These scholars conclude that Georg Wilhelm had been informed of the deteriorating situation for adherents of the reformed faith in France in the years prior to the revocation of the Edict of Nantes (1685) and that the duke issued his privilege in order to attract rich and skilled Huguenots from France. ${ }^{50}$ This position has been challenged by Thomas Klingebiel, who has stated that the privilege did not primarily aim to attract French religious exiles but to draw reformed entrepreneurs regardless of their origin to the city, who could be found in the Netherlands, England, the Hanseatic cities and Danish Altona (Holstein). ${ }^{51}$ Klingebiel argues that due to the persecution suffered by members of the reformed religion in England (and thanks to his close connections to the Netherlands) Georg Wilhelm expected refugees primarily from these locations. Klingebiel also points out that the general superintendent of Celle specifically protested against religious concessions for the foreigners from England. He thinks that it is possible that the French version of the privilege was only written when the French-reformed community was founded in Lüneburg in 1685. ${ }^{52}$ Klingebiel's analysis was critically examined by Andreas Flick who doubts the later date of the French translation of Georg Wilhelm's privilege and initially stated that a larger group of exiles could only be expected to come from France and not from England. He conceded that the privilege was perhaps deliberately formulated without naming a particular nationality in order to allow the ingress of reformed Scottish,

48. Stadtarchiv Lüneburg, Gewerbesachen, G3e No. 2, Appointment, William Waller, Celle, 30 July 1684 .

49. Andreas Flick, “„Der Celler Hof ist ganz verfranzt“: Hugenotten und französische Katholiken am Hof und beim Militär Herzog Georg Wilhelms von Braunschweig-Lüneburg”, Hugenotten, vol. 72, no. 3, 2008, p. 95; Walter Mogk, "Zur Geschichte der Evangelisch-Reformierten in Lüneburg vom 17. bis zum 19. Jahrhundert”, Niedersächsisches Jahrbuch fiur Landesgeschichte, vol. 55, 1983, pp. 382-4; Hartwig Notbohm, Geschichte der Französisch-reformierten Gemeinde — Hugenotten — in Lüneburg 1684-1839 (Lüneburg, 2001), pp. 6-8; Arnulf Siebeneicker, "Das Lüneburger Privileg", in Sabine Beneke and Hans Ottomeyer (eds), Zuwanderungsland Deutschland: Die Hugenotten (Berlin, 2005), pp. 252-3.

50. Ibid.

51. Thomas Klingebiel, Die Hugenotten in den welfischen Landen, p. 11.

52. Ibid., pp. 11-2. 
English or Dutch individuals in addition to the French into the city. ${ }^{53}$ However, after further reflecting on the subject for a decade he later concluded that it was apparently "Englishmen" and not Frenchmen who were primarily expected in Lüneburg. ${ }^{54}$

From the above it becomes evident that none of these historians have fully grasped the importance of William Waller and his goal of establishing a multi-ethnic community. The freedoms granted on 9 August 1684 were frequently described by contemporaries as the "English privileges" and the foreigners were at least in one case said to have been under the protection of the "English nation". This confirms (similarly to the terminology used in the minute book of Bremen's senate) that it was the Englishman Waller (variously mistaken as a Scot or as a French Huguenot by some historians ${ }^{55}$ ) who had negotiated the deal with the duke. Notably, Waller's own position in the duchy also depended on the successful settlement of profitable individuals. Thus we have to assume that he again welcomed the duke's decision not to exclude any nationalities from his privilege.

It has already been indicated that Georg Wilhelm himself primarily pursued economic interests with his edict in addition to secondary confessional ones. However these may have been complemented by political motivations. On 23 November 1684 it was reported that Georg Wilhelm was resolved to protect Waller and his adherents regardless of Skelton and any pressure he might attempt to bring to bear. The Duke reported that, unlike Bremen's officials, he was not intimidated by English envoys. ${ }^{56}$ This indicates that Georg Wilhelm was fully aware of the fact that he was welcoming individuals to his duchy who were seen as political dissidents in Britain. Georg Wilhelm's rhetoric against Skelton is easier to make sense of than the stance taken by the senate of Bremen. Direct trade connections with the British Isles were barely developed, and so English threats were of limited importance. Georg Wilhelm personally communicated with the city of Bremen to demand payment of Waller's outstanding salary providing both a sweetener to Waller and revealing

53. Andreas Flick, “Muss das „Lüneburger Hugenottenprivileg“" neu bewertet werden?”, Der Deutsche Hugenott, vol. 59, 1995, pp. 54-5.

54. Andreas Flick, "Hugenotten in Norddeutschland", in Evangelisch-Reformierte Gemeinde Braunschweig (ed.), Offfentlich und Ungehindert: 300 Fahre Ev.-reformierte Gemeinde Braunschweig (Braunschweig, 2004), p. 80.

55. See for example Wilhelm Beuleke, Die Hugenotten in Niedersachsen (Hildesheim, 1960), p. 137; Walter Mogk, "Geschichte der Evangelisch-Reformierten", p. 387.

56. Stadtarchiv Lüneburg, Gewerbesachen, G3e No. 2, Printed Journal Article, "Novelles Choisis et Veritables", 23 November 1684. 
the Duke's esteem for the Englishman. ${ }^{57}$ This was also reflected by the ducal council. As early as 25 July 1684 this highest administrative institution in Braunschweig-Lüneburg informed the senate of Lüneburg that several foreign individuals, predominantly Englishmen persecuted at home, were willing to settle, trade and open factories in their city provided that they were given the previously mentioned freedoms. ${ }^{58}$ The first of these Englishmen arrived before October 1684 when the ducal council reported their difficulties in receiving personal goods and merchandise from England due to the resistance of the English company of Merchant Adventurers in Hamburg. ${ }^{59}$ Although the Adventurers did not hold any authority within Braunschweig-Lüneburg they could influence the Hamburg authorities to enforce their privileges which prohibited the transport of goods belonging to Englishmen outside their company through the city to and from the North Sea. In order to assist the English incomers the ducal councillors thus resolved to re-address their goods from England as though they belonged to a senator of Lüneburg called Johann von Ciolln. They could then be shipped through Hamburg via a straw man there. ${ }^{60} \mathrm{On}$ the surface this seems to confirm Klingebiel's and (to a certain extent) Flick's hesitant statements that it was indeed mainly "Englishmen" who were expected in the city. Furthermore, contemporary reports mention an "English" assembly house in the market place and the presence of an "English" company in Lüneburg. ${ }^{61}$ However, due to the lack of demographic registers such as registers of new citizens - which are lost for the vital years between 1674 and 1700 - it is impossible to establish the number and nationality of foreigners arriving in Lüneburg after 9 August $1684 .{ }^{62}$ The only individual we can positively identify (apart from Waller) is the dyer Paul Hearne whose business in the

57. Staatsarchiv Bremen, Offiziere des Stadtmilitärs, R.5.d.13.a.19, Georg Wilhelm to Bremen Senate, Celle, 16 February 1685.

58. Stadtarchiv Lüneburg, Gewerbesachen, G3e No. 2, Ducal Councillors to Lüneburg Senate, Celle, 25 July 1684.

59. Stadtarchiv Lüneburg, Gewerbesachen, G3e No. 2, Ducal Councillors to Lüneburg Senate, Celle, 21 October 1684. The city of Hamburg was a staple city on the river Elbe which linked Lüneburg with the North Sea. Any goods traded between Lüneburg and England thus had to be transported through Hamburg - at least in theory.

60. Ibid.

61. Stadtarchiv Lüneburg, Gewerbesachen, G3e No. 2, Heinrich Meyer to Lüneburg Senate, Harburg, 18 March 1685. Meyer, an inhabitant of Harburg, petitioned the Senate of Lüneburg to omit his son, who was to settle as a nail smith in their city, from citizen duties referring to the privileges Georg Wilhelm had granted to the "English Company".

62. In addition a file of applications for citizen rights does not contain any entries for the years between 1683 and 1685. However a handful of applications for citizenship survive in the files relating to the settlement of foreigners in Lüneburg. Stadtarchiv Lüneburg, Acta von Bürgerschaften 16521699, B4 No. 71. 
duchy caused some complaints to the local authorities. ${ }^{63}$ Yet while these two Englishmen can definitively be identified, other foreigners were certainly also attracted to the duchy. Among them were several enterprising Scots. For example, Joseph Moseson was reported as one of the first foreigners to arrive in Lüneburg after the edict. He opened a small business selling tobacco, pipes and "distilled water" and was variously described as a Scot or as an English national. Notably he applied for citizen rights as an "Englishman". ${ }^{64}$ This was probably in order to make full use of Waller's growing influence in the city.

Another Scot drawn to the city by Waller was the entrepreneur Robert Hog, who had left Scotland in the early 1660s with his father, the exiled minister John Hog, himself an incumbent of the Scots church in Rotterdam. ${ }^{65}$ Waller and Hog established contact in Amsterdam where they were located before their move to Braunschweig-Lüneburg. Both men visited the ducal council in Celle in September 1684 in order to negotiate the establishment of a cloth factory in Lüneburg with a plan to produce fine cloth worth 40,000 Imperial dollars annually. ${ }^{66}$ Hog opened his business later the same year with his Dutch business partner Anton de Pau. The enterprise was located in the so-called Wandhaus (cloth house) and included a mill as well as a place where finished cloth could be dyed. Soon after their arrival Hog and Pau sought to expand into other buildings and the senate discussed offering them the Marstall (city stables) or the house of a Mr Elwer for their enterprise. ${ }^{67} \mathrm{In}$ addition to this, both entrepreneurs successfully urged the senate to provide a hall for the sale of cloth. ${ }^{68}$ The production depended largely on the use of child labour and the senate had obliged itself to find at least 150 young male and female workers aged between twelve and fourteen who were to stay in the factory for seven years to be replaced thereafter. ${ }^{69}$ Nevertheless, Hog and

63. Stadtarchiv Lüneburg, Gewerbesachen, G3e No. 2, Report of Complaints, Lüneburg Senate, Celle, 28 July 1685.

64. Stadtarchiv Lüneburg, Gewerbesachen, G3e No. 2, Confirmation of Privileges applying to Joseph Moseson, 24 October 1684; G3e No. 2, Complaints, Lüneburg Senate to Ducal Council Lüneburg, 29 August 1685.

65. NAS, Leven and Melville Papers, GD26/13/492, Robert Hog to the Earl of Leven, Lüneburg, 20 January 1709; Gardner, The Scottish Exile Community, p. 31.

66. Stadtarchiv Lüneburg, Gewerbesachen, G3e No. 2, Minutes of the Ducal Chamberlain Albrecht Ramdohr's proposition concerning Hog's factory, Celle, 26 September 1684.

67. Stadtarchiv Lüneburg, Gewerbesachen, G3e No. 22, Memorial, Robert Hog / Anton Pau to Lüneburg Senate, Lüneburg, 12 June 1685 and 7 September 1685.

68. Ibid.

69. Stadtarchiv Lüneburg, Gewerbesachen, G3e No. 2, Minutes of the Ducal Chamberlain Albrecht Ramdohr's proposition concerning Hog's factory, Celle, 26 September 1684; G3e No. 2, Lüneburg Senate to Georg Wilhelm, Lüneburg, 29 September 1684; G3e No. 22, Record of the Ducal Council concerning Robert Hog, Celle, 10 October 1684. 
Pau also employed a number of skilled adult workers from the Netherlands. For example, at least four Dutchmen were working as chief servants (Meisterknechte) in the factory, their tasks lying mainly in supervising the children's work. ${ }^{70}$ Furthermore, the entrepreneurs drew at least seven cloth processors (Tuchbereiter) to the city, who were to receive their own guild roll in 1686 and who in turn employed a number of apprentices from the Netherlands, the cities of Lübeck and Bremen and other neighbouring places. ${ }^{71}$ Another person in a trusted position was Paul Behrenberg who was to administer the business and to act as master of the sales hall from October 1685 but it is unclear where he originated from. ${ }^{72}$ In November 1684 Hog's sister Margaret arrived in Lüneburg and was supposed to run the business side of the factory. Her brother planned to direct the factory from Amsterdam and to base himself there in the long term. ${ }^{73}$ The latter confirms that Hog was in no immediate danger in the Netherlands and that his move to Lüneburg was due to the economic opportunities offered by Waller and Georg Wilhelm's edict. Nevertheless, his exile background made Hog sympathetic to the Scottish religious exiles' cause and he became involved in one of their financial networks on at least one occasion. On 2 November 1685 the Scottish exiled minister James Brown asked Andrew Russell to remit money via Robert Hog to the Scottish merchant in Königsberg, Mr Andrew Marshall, showing his trust in the entrepreneur. ${ }^{74}$

From the above it becomes clear that several foreigners of different nationalities were directly or indirectly attracted to Lüneburg. Their number also included French Huguenots like the entrepreneurs Vincent $\mathrm{du}$ Bois and Jean Rossier Sorans who tried to establish their own enterprises in the city, but who were ultimately unsuccessful. ${ }^{75}$ Although the foreigners adhered to the reformed faith, differences existed in their confessions and it is thus not clear if they worshipped together or if several private churches were established. Fortunately there is evidence

70. Stadtarchiv Lüneburg, Gewerbesachen, G3e No. 36, Chief Servants to Lüneburg Senate, Lüneburg, 27 March 1686.

71. Stadtarchiv Lüneburg, Gewerbesachen, G3e No. 36, Lübeck Senate to Lüneburg Senate, Lübeck, 20 January 1686; G3e No. 36, List of Cloth Processors, without date/place.

72. Stadtarchiv Lüneburg, Gewerbesachen, G3e No. 22, Robert Hog to Lüneburg Senate, Lüneburg, 7 October 1685.

73. Stadtarchiv Lüneburg, Gewerbesachen, G3e No. 22, Ducal Council to Lüneburg Senate, Celle, 24 November 1684.

74. NAS, Russell Papers, RH15/106/576, James Brown to Andrew Russell, Danzig, 2 November 1685; Steve Murdoch, Network North, p. 113.

75. Walter Mogk, "Geschichte der Evangelisch-Reformierten”, p. 387. 
that Waller aimed to set up a church in his own house. ${ }^{76}$ An estimate he obtained of the costs of church furniture from a local craftsman allows for some conclusions to be drawn on the size and social structure of the reformed congregation Waller envisaged for Lüneburg. The furniture was to include a special seat for Waller himself with a baldachin (Himmel), as well as benches which could seat 55 members of the gentry and nobility as well as 21 additional ordinary benches reserved for common people. ${ }^{77}$ This suggests that the congregation was to accommodate well over 100 individuals with Waller himself taking a prominent position within it. Nevertheless, we do not know who exactly was to worship within this church nor does the cost estimate prove that the church ever materialised in this form. However, in 1686 Waller requested half of the salary offered by the duke for the two reformed ministers to be paid to a Scot, William Douglas, indicating the presence of a British congregation similar to the ones which can be found in other places such as Elbing. ${ }^{78}$

By a process of elimination we can demonstrate that the English and Scottish exiles worshipped almost exclusively in their own church rather than with other foreigners. On 16 March 1685 a French reformed church was established under the guidance of the French minister Joseph de Casaucau, who arrived from Copenhagen. ${ }^{79}$ It was almost certainly he who received the other half of the minister's salary provided by the duke. The church book of the French congregation partially survives and has been analysed by Beuleke who - in correlation with other documentsidentified 33 men and 30 women as belonging to the French community between 1685 and the beginning of the eighteenth century. ${ }^{80}$ As no English, Scottish or Dutch names appear in the registers - apart from two exceptions ${ }^{81}$ — we can conclude that exiles of these nationalities continued to worship in their own private church, giving credit to the notion

76. Stadtarchiv Lüneburg, Gewerbesachen, G3e No. 2, Bill Relating to Church Pews, Lüneburg, 4 November 1684; Protocoll Curiae 1684-1685, P7 No. 17, p. 65, 18 November 1684.

77. Stadtarchiv Lüneburg, Gewerbesachen, G3e No. 2, Bill Relating to Church Pews, Lüneburg, 4 November 1684. The German text does not differentiate between gentry and nobility but uses the term Adlige. However, it has to be assumed that Waller anticipated attracting members of the gentry primarily. The senate was prepared to give Waller some chairs for the nobles/members of the gentry. Stadtarchiv Lüneburg, Protocoll Curiae 1684-1685, P7 No. 17, p. 65, 18 November 1684.

78. Henri Tollin, "Geschichte der hugenottischen Gemeinde in Celle", Der deutsche Hugenott, 5, 1899, p. 6. Tollin got his information from a document in the state archives in Hanover from a file which could so far not be localised. (The old reference states Staatsarchiv Hannover, Celle Br. Arch. Des. 55, Lüneburg No. 682.)

79. Andreas Flick, "Hugenotten in Norddeutschland", p. 80; Walter Mogk, "Geschichte der Evangelisch-Reformierten", p. 389.

80. Wilhelm Beuleke, Die Hugenotten in Niedersachsen, pp. 134-7.

81. Ibid. Waller's daughter Catherine married the Frenchmen Richard de Courtenay on 19 November 1685. Also Mary Taylor from London married in the French church on 15 August 1685. 
that Waller's was in fact built. It is unclear who the 55 members of the nobility and gentry were that Waller hoped to draw to Lüneburg. It is possible that they included the entrepreneurs Hog and Pau, both of whom carried the prefix "de" in their name indicating their high ranking status. ${ }^{82}$ However, as argued previously, Waller's main target lay not solely in the establishment of a reformed exile community but in the creation of a safe haven for political dissidents who were in immediate danger in the United Provinces. These were mainly members of the nobility and gentry and they were probably meant to form the majority of high ranking individuals in Waller's church.

One of these exiles, the Scot Sir John Cochrane, arrived in Lüneburg in October 1684 together with his son as well as several other unnamed adherents. ${ }^{83}$ After having established links with the earl of Argyll and the inner circle of the duke of Monmouth in early 1683, Cochrane had become suspected of involvement in the conspiracy to overthrow Charles II — an accusation of which he was found guilty in May 1685 with the result that his estates were foreited. In addition the Scottish Privy Council had directed the king's advocate on 16 August 1683 to charge Cochrane with treason for his involvment in the Bothwell Bridge rising. Thus Cochrane had been forced to escape to the Netherlands, from where he moved to the duchy of Cleves and then on to Lüneburg via Hanover. ${ }^{84}$ However, his stay was only short as he played an active part in the ill-fated Argyll Rebellion in 1685 and it is likely that the individuals he had brought to Lüneburg followed him back to the British Isles. ${ }^{85}$

Apart from Cochrane (and Waller) it is not possible to identify other exiles or suspected anti-Stuart conspirators in Lüneburg, but this of course does not mean that they were not there. We know that Waller continued in his endeavours to attract entrepreneurs to the city. In the end of 1685 he as well as an (unnamed) Englishman inspected possible locations for a serge factory. In addition to 500 local children, a considerable number of 100 to 200 skilled workers from England and other places were to be employed in this factory. ${ }^{86}$ However, negotiations with the senate proved difficult and Waller threatened that the entrepreneur had already

82. For evidence that Scots used this device to highlight their status abroad see Steve Murdoch, "The Pearl Fisher Robert Buchan 'de Portlethin' in Sweden", Northern Studies (2007), pp. 51-70.

83. Stadtarchiv Lüneburg, Gewerbesachen, G3e No. 2, Johan Halfe to Lüneburg Senate, 11 October 1684 .

84. Richard L. Greaves, "Sir John Cochrane (1662-1695)", DNB (online publication).

85. Ibid.

86. Stadtarchiv Lüneburg, Gewerbesachen, G3e No. 7, Privileges Demanded by the Manufacturers, 11 December 1685. 
received a better offer in East Frisia. ${ }^{87}$ Although the senate eventually granted privileges to the Englishman there is no further proof that the factory ever materialised. ${ }^{88}$ Furthermore, at least one source states that William Waller took his leave from Lüneburg on 15 June 1686, apparently to return to Bremen where he would receive another military command - giving further evidence that the establishment of the serge factory failed. ${ }^{89}$

Waller's departure from the city must have had a profound impact on the exiles. Developments in the political situation of the British Isles negated the need for an exile community and most British exiles left the continent after the Williamite Revolution (1688/1689). However, there were exceptions. Robert Hog remained in production in Lüneburg until at least 1709. The fact that he decided to stay in Lüneburg perhaps confirms that he was primarily concerned with economic matters and not overtly emotionally attached to the exiles' cause. Alternatively, he may have simply found the financial gains of his enterprises abroad too rewarding to give up at that juncture. Furthermore, he may have integrated into Lüneburg's society through marriage or other links which he was perhaps not prepared to surrender. Nevertheless, Hog maintained an interest in his home country despite his long-term absence. This was expressed in 1709 when Hog recommended his son John to the Earl of Leven, stating that he had sent him to his native country to learn the language. ${ }^{90}$ Furthermore, Hog — as a "true Scot" - praised the effects which the parliamentary Anglo-Scottish Union of 1707 could potentially have on Scotland if people knew how to make use of the liberty of freely using Irish and English wool. He described his comfortable life in Lüneburg but stated that he was willing to return to Scotland after his 46 years abroad provided that the monarch would allow him a small pension. He further implied that he would then use his expertise to the benefit of the country's economy stating that he "brogt the Lunenburg manufactory to perfection" and that "al my countrymen in Scotland know there could be no better man to give directions". ${ }^{91}$ It is not clear why Hog waited for almost two years after the Union before sending this letter. It is possible that he wanted to confirm that the Union was secure as evidenced by the

87. Stadtarchiv Lüneburg, Gewerbesachen, G3e No. 7, William Waller to Georg Wilhelm, Gelle, 3 February 1686.

88. Stadtarchiv Lüneburg, Gewerbesachen, G3e No. 7, Lüneburg Senate to Ducal Council, 26 January 1686.

89. Wilhelm Beuleke, Die Hugenotten in Niedersachsen, p. 137.

90. NAS, Leven and Melville Papers, GD26/13/492, Robert Hog to the Earl of Leven, Lüneburg, 20 January 1709.

91. Ibid. 
failure of the 1708 Jacobite uprising. ${ }^{92}$ His revived interest in Scotland may have been partially financially motivated. However, his position in Lüneburg (unless exaggerated in his letter) suggests that Hog felt genuinely attached to Scotland, perhaps simply wishing to retire there.

Waller's negotiations with the senate of Bremen and Georg Wilhelm of Braunschweig-Lüneburg demonstrate that the interest of British exiles was not limited to the United Provinces. When life in the Dutch cities became too dangerous for some political exiles new places were sought to establish multi-ethnic reformed communities which could provide shelter to a smaller number of endangered individuals. The Imperial city of Bremen and the duchy of Braunschweig-Lüneburg provided obvious choices for the establishment of these communities as they either embraced or at least tolerated Calvinist churches. However, both communities envisaged by Waller were faced with severe difficulties. In Bremen these seemed to come from the outside. It was the pressure from Charles II and Bevil Skelton in Hamburg which forced the Bremen authorities to release Waller and to give up the proposed "British" community. In Lüneburg incomers like Hearne faced complaints and resistance from the local population who feared their competition. This was especially so as the decision to attract foreigners had not been made by the city's authorities but by the ducal authorities at Celle. Despite these difficulties individuals like Hog were successful in the long term. He remained in Lüneburg after the Williamite Revolution revealing that to some exiles mercantile considerations were just as important as spiritual or political concerns. However, the Scottish entrepreneur was an exception in that most exiles left the continent after the Stuart regimes had ended. Nevertheless, for a short time, the duchy of Braunschweig-Lüneburg (and to a lesser extent the city of Bremen) had offered them support and the opportunity of building a reformed community in a mutually beneficial relationship with fellow refugees of other nationalities.

92. Daniel Szechi, The Jacobites: Britain and Europe, 1688-1788 (Manchester, 1994), pp. 56-7. 